\title{
KEDUDUKAN SITA PIDANA TERHADAP SITA UMUM KEPAILITAN
}

\section{Josua Fernando}

(Mahasiswa Program S1 Fakultas Hukum Universitas Tarumanagara)

(E-mail: josuafernando45@gmail.com)

\section{Susanti Adi Nugroho}

(Corresponding Author)

(Dosen Hukum Kepailitan Fakultas Hukum Universitas Tarumanagara, Meraih Sarjana Hukum dari

Fakultas Hukum Universitas Diponegoro, Magister Hukum dari Fakultas Hukum Universitas Pelita Harapan, Doktor Hukum dari Fakultas Hukum Universitas Padjajaran)

(E-mail: susanti_nugroho@yahoo.com)

\begin{abstract}
The Court Ruling claim that a debt discharge a bankruptcy inflict a debtor will loose his right to dominate the wealth which include the bankruptcy property. The whole riches of a debt who's discharge bankruptcy, automatically will be placed to the general confiscation. The general confiscation of the debt property has intend to protect the interest of the creditor of all the deeds of the debt which can disserve the property of a bankruptcy and stop the execution of the debt property with all the creditors to get the debt repayment. The general confiscation itself is a form of confiscation which known in civil law regime especially bankruptcy in legal perspective as a private law. Confiscation in a criminal case aim to prove criminal act. Article 38 of a Criminal Code Procedure regulate that the investigator can undertake the property of confiscation that placed in the general confiscation. However, Article 46 of a Bankruptcy and Suspension Of Obligation For payment Of Debt regulate that all confiscation become vanished when the property has confiscated in the general confiscation. When this two confiscation situated in the property, The confiscation in criminal case will precede the general confiscation. That matter is because of the confiscation in a criminal case is part of public law that aimed to protect our public interest.
\end{abstract}

Keywords : bankruptcy, general confiscation, criminal confiscation, public interest 


\section{PENDAHULUAN}

\section{A. Latar Belakang}

Kepailitan berdasarkan UUK-PKPU adalah sita umum atas semua kekayaan debitur pailit yang pengurusan dan pemberesannya dilakukan oleh Kurator di bawah pengawasan hakim pengawas ${ }^{1}$. Sedangkan pailit merupakan suatu keadaan di mana debitur tidak mampu untuk melakukan pembayaran terhadap utang-utang dari pada krediturnya. Keadaan tidak mampu membayar lazimnya disebabkan karena kesulitan kondisi keuangan (financial distress) dari usaha debitur yang telah mengalami kemunduran ${ }^{2}$.

Ketentuan kepailitan merupakan aturan yang mempunyai tujuan untuk melakukan pembagian harta debitur kepada para krediturnya dengan melakukan sita umum terhadap seluruh harta debitur yang selanjutnya dibagikan kepada kreditur sesuai dengan hak proporsinya. Kepailitan sendiri merupakan pengejawantahan dari prinsip paritas creditorium dan prinsip pari passu prorate parte dalam rezim hukum harta kekayaan ${ }^{3}$.

Prinsip paritas creditorium dianut di dalam sistem hukum perdata di Indonesia, prinsip tersebut dimuat dalam Pasal 1131 KUH Perdata dan Pasal 1132 KUH Perdata yang menurut Kartini Mulyadi bahwa rumusan dalam Pasal 1131 KUH Perdata menunjukkan bahwa setiap tindakan yang dilakukan seseorang dalam lapangan harta kekayaan selalu akan membawa akibat terhadap harta kekayaannya, baik yang bersifat menambah jumlah harta kekayaan (kredit), maupun yang nantinya akan mengurangi jumlah harta kekayaannya (debit). Sedangkan jika ternyata dalam hubungan hukum harta kekayaan tersebut, seseorang memiliki lebih dari satu kewajiban yang harus dipenuhi terhadap lebih dari satu orang yang berhak atas pemenuhan kewajiban tersebut, maka Pasal 1132 KUH Perdata menentukan bahwa

\footnotetext{
${ }^{1)}$ Indonesia, Undang-undang Nomor 37 Tahuun 2004 Tentang Kepailitan dan Penundaan Kewajiban Pembayaran Utang (Lembaran Negara Republik Indonesia Tahun 2004 Nomor 131, Tambahan Lembaran Negara Republik Indonesia Nomor 4443), Pasal 1 ayat 1.

${ }^{2)}$ M. Hadi Shubhan, Hukum Kepailitan Cetakan ke-2. (Jakarta: Prenadamedia Group, 2009), hal. 1.

${ }^{3)}$ Ibid., hal. 5.
} 
setiap pihak atau kreditur yang berhak atas pemenuhan perikatan haruslah mendapat pemenuhan perikatan dari harta kekayaan pihak yang berkewajiban (debitur) tersebut secara pari passu, (secara bersama-sama memperoleh pelunasan, tanpa ada yang didahulukan), dan pro rata, (proporsional yang dihitung berdasarkan pada besarnya piutang masing-masing dibandingkan terhadap piutang mereka secara keseluruhan, terhadap harta kekayaan debitur tersebut $)^{4}$.

Putusan pengadilan yang menyatakan seorang debitur pailit mengakibatkan debitur demi hukum akan kehilangan hak untuk menguasi dan mengurus harta kekayaan yang termasuk dalam harta pailit dan seluruh harta kekayaan debitur secara otomatis akan diletakkan sita umum. Diletakkannya sita umum atas semua kekayaan debitur bertujuan untuk melindungi kepentingan kreditur terhadap perbuatan debitur yang dapat merugikan harta pailit dan untuk menghentikan eksekusi harta debitur oleh para krediturnya untuk mendapatkan pelunasan piutangnya masing-masing. Peletakkan sita umum pula dapat memaksimalkan pengumpulan harta pailit guna pembayaran kepada seluruh kreditur, dengan terkumpulnya harta debitur secara maksimal maka seluruh hutang debitur dapat dibayar secara maksimal pula sehingga proses kepailitan (bankruptcy) tidak sia-sia. Semua kekayaan debitur pailit yang telah diletakkan sita umum nantinya akan diurus oleh kurator di bawah pengawasan hakim pengawas.

Sita umum merupakan bentuk penyitaan yang dikenal dalam rezim hukum perdata khususnya hukum kepailitan yang bersifat privat. Didalam hukum publik dalam hal ini hukum pidana juga mengenal sita yang didalam Kitab Undang-undang Hukum Acara Pidana (KUHAP) disebut dengan penyitaan yang dalam bahasa Belanda dikenal dengan istilah "inbesilagneming". Penyitaaan dalam KUHAP diatur secara terpisah dalam dua tempat, sebagian besar diatur dalam Bab V, bagian

\footnotetext{
${ }^{4)}$ M. Hadi Shubhan, Op. Cit., hal. 4.

${ }^{5)}$ M. Yahya Harahap, Pembahasan Permasalahan Dan Penerapan KUHAP Penyidikan dan Penuntutan, Edisi Kedua, (Jakarta: Sinar Grafika, 2001), hal. 264.
} 
keempat Pasal 38 sampai dengan Pasal 46 KUHAP dan sebagian kecil diatur dalam Bab XIV.

Penyitaan dalam Pasal 1 angka 16 didefiniskan sebagai serangkaian tindakan penyidik untuk mengambil alih dan atau menyimpan dibawah penguasaannya benda bergerak atau tidak bergerak, berwujud atau tidak berwujud untuk kepentingan pembuktian dalam penyidikan, penuntutan dan peradilan. Penyitaan merupakan suatu tindakan "upaya paksa" yang dilakukan penyidik mengandung penghinaan dan perkosaan serta bertentangan dengan nilai Hak asasi Manusia, namun disisi lain demi untuk kepentingan umum dalam rangka menyelesaiakan perkara pidana, secara eksepsional undang-undang membenarkan penyitaan ${ }^{6}$. Karena penyitaan merupakan bentuk "upaya paksa" yang dapat bertentangan dengan hak asasi manusia, penyitaan yang dilakukan oleh penyidik haruslah berdasarkanan para surat izin Ketua Pengadilan Negeri sebagaimana yang diatur didalam Pasal 38 Ayat (1) KUHAP, dalam Ayat (2) menyebutkan dalam keadaan yang sangat perlu dan mendesak bilamana penyidik harus bertindak dan tidak mungkin untuk mendapatkan surat izin terlebih dahulu, KUHAP memberikan pengecualian.

Pasal 39 ayat (1) dan ayat (2) KUHAP mengatur benda yang dapat disita oleh penyidik termasuk didalamnya benda yang berada dalam sitaan karena perkara perdata atau karena pailit dapat pula disita untuk kepentingan penyidikan, penuntutan dan mengadili perkara pidana. Pasal 39 Ayat (2) KUHAP memberikan legitimasi kepada penyidik untuk melakukan penyitaan terhadap benda yang telah berada dibawah sita umum kepailitan, keberadaan Pasal 39 Ayat (2) KUHAP berbenturan dengan Pasal 31 Ayat (2) UUK-PKPU yang menyatakan bahwa semua penyitaan yang telah dilakukan menjadi hapus dan jika di perlukan Hakim Pengawas harus memerintahkan pencoretan.

Kedua pasal ini menimbulkan benturan dan permasalahan dalam penerapannya. Salah satu kasus yang berkaitan tentang sita umum yang kemudian di sita pidana

\footnotetext{
${ }^{6)}$ Ibid, hal. 276.
} 
ialah kasus Koperasi Pandawa Mandiri Group. Koperasi Pandawa Manidiri Group berdasarkan Putusan No. 37/Pdt-Sus-PKPU/2017/PN Niaga Jkt.Pst dinyatakan pailit bersamaan dengan pendirinya yang juga sekaligus pengurus yakni Salman Nuryanto. Konsekuensi hukum dengan adanya pernyataan pailit tersebut sebagaimana disebutkan diawal bahwa seluruh harta benda milik debitor pailit akan diletakkan sita umum. Setelah diletakkan sita umum, Salman Nuryanto diduga telah melakukan tindak pidana melanggar Pasal 46 Ayat (1) Undang-Undang (UU) Nomor 10 Tahun 1998 Tentang Perubahan Atas UU Nomor 7 Tahun 1992 Tentang Perbankan, jo Pasal 69 UU Nomor 21 Tahun 2011 Tentang OJK, jo Pasal 55 ayat (1) ke-1 jo Pasal 64 Ayat (1) KUHP dan Pasal 378 KUHP Tentang Penipuan, jo Pasal 55 ayat (1) jo Pasal 64 ayat (1) KUHP. Dengan adanya dugaan tindak pidana yang dilakukan oleh Salman Nuryanto yang merupakan pendiri dan juga pengurus dari KSP Pandawa Mandiri Group, penyidik melakukan penyitaan terhadap benda yang telah diletakkan sita umum.

Akibatnya terdapat dua sita diatas satu benda padahal Pasal 436 Rv mengatur bahwa barang yang telah diletakkan sita, tidak bisa dilakukan sita untuk kedua kalinya. Hal ini menegaskan bahwa tidak dimungkinkan meletakkan sita umum kepailitan dan sita pidana dalam waktu yang bersamaan. Dengan adanya benturan antara sita umum dan sita pidana berakibat timbulnya ketidakpastiaan hukum, agar terciptanya kepastiaan hukum harus ditentukan bagaimana sebenarnya kedudukan sita pidana atas sita umum kepailitan.

\section{B. Permasalahan}

Berdasarkan uraian latar belakang di atas, maka permaslahan yang hendak dirumuskan adalah: Bagaimana Kedudukan Sita Pidana Terhadap Sita Umum Kepailitan?

\section{PEMBAHASAN}

\section{A. Hasil Penelitian}




\section{Pengertian Kepailitan}

Istilah kepailitan merupakan kata benda yang berakar dari kata "pailit". Sedangkan kata "pailit" berasal dari kata "failit" dalam bahasa Belanda. Dari istilah "failit" muncul istilah "faillissement" yang diterjemahkan ke dalam bahasa Indonesia menjadi "kepailitan". Dari istilah "faillissement" muncul istilah "faillissementwet" (Undang-undang Kepailitan Belanda) dan Faillissements-Verordening (Undang-undang Kepailitan Hindia-Belanda) yang berarti ("Undang-Undang Kepailitan"). "Faillissement" dan "kepailitan" merupakan padanan istilah "bankruptcy" atau "insolvency" dalam bahasa inggris ${ }^{7}$.

Menurut Munir Fuady yang dimaksud dengan pailit atau bangkrut adalah suatu sitaan umum atas seluruh harta debitur agar dicapainya perdamaian antara debitur dan para kreditur atau agar harta tersebut dapat dibagi-bagi secara adil di antara para kreditur ${ }^{8}$. R. Subekti mengartikan kepailitan sebagai suatu usaha bersama untuk mendapatkan pembayaran bagi semua orang yang berpiutang secara adil $^{9}$.

Didalam UUK-PKPU, Kepailitan adalah sita umum atas semua kekayaan debitur pailit yang pengurusan dan pemberesannya dilakukan oleh kurator di bawah pengawasan hakim pengawas. Secara sederhana, kepailitan dapat diartikan sebagai suatu penyitaan semua aset debitur yang dimasukkan ke dalam permohonan pailit yang digunakan untuk melunasi utang debitur kepada kreditur yang pengurusannya dilakukan oleh kreditur.

\section{Syarat Kepailitan}

Syarat kepailitan merupakan satu hal paling terpenting dalam UUKPKPU, syarat kepailitan yang diatur didalam UUK-PKPU merupakan tolak ukut bagi pengadilan untuk menetapkan apakah permohonan pailit yang diajukan oleh kreditur ataupun debitur itu sendiri memenuhi syarat untuk menetapkan debitur pailit.

\footnotetext{
${ }^{7)}$ M. Hadi Shubhan, Op. Cit., hal. 2.

${ }^{8)}$ Munir Fuady, Hukum Pailit, (Bandung : Citra Aditya Bakti, 2002), hal. 8.

${ }^{9}$ R. Subekti, Pokok-Pokok Hukum Dagang, (Jakarta: Intermasa, 1995), hal. 2.
} 
Syarat-syarat kepailitan dalam UUK-PKPU ditentukan dalam Pasal 2 ayat (1) yaitu ${ }^{10}$ :

Debitur yang mempunyai dua atau lebih kreditur dan tidak membayar lunas sedikitnya satu utang yang telah jatuh waktu dan dapat ditagih, dinyatakan pailit dengan putusan pengadilan, baik atas permohonannya sendiri maupun atas permohonan seorang atau lebih krediturnya.

Dari ketentuan Pasal 2 ayat (1) UUK-PKPU, dapat disimpulkan bahwa permohonan pernyataan pailit terhadap seorang debitur hanya dapat dikabulan apabila memenuhi syarat-syarat sebagai berikut:

a) Debitur harus paling sedikit mempunyai dua kreditur; atau dengan kata lain harus memiliki lebih dari satu kreditur.

b) Debitur tidak membayar lunas sedikitnya satu utang kepada salah satu krediturnya.

c) Utang yang tidak dibayar itu harus telah jatuh waktu dan telah dapat ditagih (due and payable).

\section{Pengertian dan Jenis Sita}

Penyitaan berasal dari terminology beslag (belanda) ${ }^{11}$ dan istilah Indonesia beslah tetapi istilah bakunya ialah sita atau penyitaan.Kamus hukum ekonomi memberi pengertian penyitaan adalah penitipan barang sengketa kepada pihak ketiga, yang ditunjuk oleh pihak-pihak yang bersengketa atau oleh pengadilan.Pihak ketiga wajib menyerahkan barang sengketa itu kepada pihak yang dinyatakan berhak setelah terdapat putusan pengadilan.

M. Yahya Harahap sendiri memberi pengertian penyitaan adalah :

10)Indonesia, Undang-undang Nomor 37 Tahuun 2004 Tentang Kepailitan dan Penundaan Kewajiban Pembayaran Utang (Lembaran Negara Republik Indonesia Tahun 2004 Nomor 131, Tambahan Lembaran Negara Republik Indonesia Nomor 4443), Pasal 2 ayat 1.

11) ) M. Yahya Harahap, Hukum Acara Perdata tentang Gugatan, Persidangan, Penyitaan, Pembuktian, dan Putusan Pengadilan, (Jakarta: Sinar Grafika, 2009), hal. 282. 
- Tindakan menempatkan harta kekayaan tergugat secara paksa berda ke dalam keadaan penjagaan (to take into custody the property of a defendant),

- Tindakan paksa penjagaan (custody) itu dilakukan secara resmi (official) berdasarkan perintah pengadilan atau hakim.

- Barang yang ditempatkan dalam penjagaan tersebut, berupa barang yang disengketakan, tetapi boleh juga barang yang akan dijadikan sebagai alat pembayaran atau pelunasan utang debitur atau tergugat, dengan jalan menjual lelang (executorial verkoop) barang yang disita tersebut.

\section{Tujuan dari Sita dan Jenis-jenis Sita dalam Hukum Perdata}

Tujuan dari sita adalah upaya untuk menjamin pelaksanaan suatu putusan hakim dikemudian hari atas barang-barang milik tergugat baik benda bergerak maupun benda tetap selama proses perkara belangsung. Dengan demikian barang-barang yang disita tidak dapat dialihkan, diperjualbelikan, disewakan atau dipindahtangankan kepada pihak lain oleh pihak penggugat yang beritikad buruk (bad faith) $)^{12}$. Dengan mengaitkan tujuan penyitaan dengan ketentuan Pasal 199 HIR, 214 Rbg dan Pasal 231 KUH Perdata, terjamin perlindungan yang kuat penggugat atas terpenuhinya pelaksanaan putusan pengadilan pada saat eksekusi dijalankan.

Ada tujuan lain yang tidak kalah penting dalam penyitaan, selain dari memberi kepastian kepada penggugat bahwa gugatannya telah dijamin dan mempunyai arti dan nilai apabila gugatannya dikabulkan oleh pengadilan, yaitu adanya sita, berarti sudah ada secara pasti objek eksekusi atas kemenangan penggugat, atau disimpulkan objek eksekusi sudah pasti. Hal ini menjaga agar kemenangan penggugat tidak ilusioner (hampa) sehingga kemenangan penggugat ada suatu materinya, yakni barang yang disita tersebut

${ }^{12)}$ Muhammad Nasir, Hukum Acara Perdata, Djambatan, (Jakarta: Djambatan, 2005), hal. 89. 
Dikenal ada dua macam sita yaitu sita terhadap benda milik penggugat (kreditur) dan sita terhadap barang milik tergugugat (debitur).

A. Sita jaminan terhadap benda milik penggugat (kreditur)

Sita jaminan dilakukan terhadap benda milik penggugat yang dikuasai oleh tergugat atau orang lain/pihak ketiga.Sita jaminan ini tidak dimaksudkan untuk menjamin suatu tagihan utang yang berupa uang, melainkan untuk menjamin suatu hak kebendaan dari penggugat (pemohon atau kreditur) dan berakhir dengan penyerahan (levering) benda yang disita itu. Sita jaminan terhadap benda milik penggugat sendiri dikenal ada dua macam yaitu sita revindikasi dan sita marital ${ }^{13}$

a. Sita Revindikasi /revindicatoir beslag (Pasal 226 HIR dan 260 $\mathrm{Rbg}$ )

Sita revindikasi adalah sita yang dimohonkan, baik secara tertulis atau lisan, oleh pemilik suatu benda bergerak yang sedang dikuasai oleh tergugat atau pihak lain, melalui pengadilan negeri di tempat orang yang menguasai benda tersebut tinggal ${ }^{14}$.

b. Sita marital/maritaal beslag

Sita marital adalah sita yang ditujukan untuk menjamin agar barang yang disita tidak dialihkan atau diasingkan oleh pihak lawan, dan bukan ditujukan untu menjamin tagihan utang atau penyerahan barang. Sita marital ini dapat dimohonkan kepada pengadilan negeri oleh seorang istri yang tunduk kepada $\mathrm{KUH}$ Perdata, selama sengketa perceraiannya diperiksa di pengadilan, terhadap barang-barang tersebut ${ }^{15}$.

B. Sita jaminan terhadap benda bergerak milik debitur.

\footnotetext{
${ }^{13)}$ Muhammad Nasir, Op. Cit., hal. 90.

${ }^{14)}$ Ibid., hal. 90.

${ }^{15)}$ Pasal 190 KUH Perdata dan Pasal 823 Rv.
} 
Sita jaminan atau conservatoir beslag adalah sita jaminan terhadap benda-benda milik tergugat baik terhadap benda bergerak maupun tidak bergerak yang dijadikan jaminan untuk pelunasan utang atau pemenuhan prestasi ${ }^{16}$.

Dalam sita jaminan, yang dapat menjadi objek permohonan sita adalah:

a. benda bergerak milik debitur;

b. benda tidak bergerak milik;

c. benda bergerak milik debitur yang berada di tangan pihak ketiga $^{17}$.

Pasal 227 ayat (1) HIR dan Pasal 261 ayat (1) Rbg menentukan bahwa sita jaminan hanya dapat dilakukan atas perintah Ketua Pengadilan Negeri karena adanya permintaan kreditur atau penggugat. Secara faktual dalam proses pengadilan, penggugat mengajukan permohonan sita jamina ini kepada hakim yang memeriksa perkara tersebut, yang selanjutnya hakim membuat penetapan. Hal ini disebabkan karena sita jaminan itu telah menjurus dalam pemeriksaan perkara pokok. Oleh karena itu, hakim yang memeriksa perkara tersebut itulah yang dapat memerintahkan sita jaminan dengan surat penetapannya. Permohonan sita jaminan bukanlah suatu tuntutan hak yang bebas dan berdiri sendiri, melainkan selalu berkaitan dengan pokok perkara. Namun demikian, ada beberapa kemungkinan kombinasi antara sita jaminan dengan pokok perkara yaitu:

a. Sita jaminan diajukan secara bersama-sama dengan pokok perkara

b. Sita jaminan diajukan secara terpisah dengan pokok perkara $^{18}$.

\footnotetext{
${ }^{16)}$ Sarwono, Hukum Acara Perdata Teori dan Praktik, (Jakarta: Sinar Grafika, 2011), hal. 152-153.

${ }^{17)}$ Putusan Mahkamah Agung No. 476/K/1974 tanggal 14 Novembe 1974.
} 


\section{Sita Umum}

Kepailitan adalah sita umum atas semua harta kekayaan debitur pailit yang pengurusan dan pemberesannya didlakukan oleh kurator di bawah pengawasan hakim pengawas sebagaimana diatur di dalam UUK-PKPU ${ }^{19}$. Sita umum (public attachment, gerechtelijk beslag) dilakukan terhadap seluruh harta debitur agar dicapainya suatu perdamaian antara debitur dengan para krediturnya atau agar harta tersebut dibagi-bagi secara adil di antara para krediturnya ${ }^{20}$.

Sita umum berlaku atas seluruh harta debitur baik yang sudah ada maupun yang diperoleh selama proses kepailitan ${ }^{21}$. Harta debitur menjadi jaminan bersama bagi semua kreditur dan hasil penjualan barang-barang tersebut dibagi menurut perbandingan piutang masing-masing kecuali bila di antara para kreditur tersebut mempunyai alasan yang sah untuk didahulukan ${ }^{22}$.

Dengan adanya putusan pernyataan pailit debitur demi hukum kehilangan haknya untuk menguasai dan mengurus kekayaannya yang termasuk dalam harta pailit dengan adanya putusan tersebut pula seluruh kekayaan debitur baik yang telah ada ataupun yang diperoleh selama proses kepailitan secara otomatis akan diletakkan sita umum. Sitaan terhadap seluruh kekayaan debitur merupakan bagian dari pengelolaan harta pailit (management of estate) yang dikelola berdasarkan suatu metode sistematik untuk mengurus harta kekyaan debitur selama menunggu proses kepailitan ${ }^{23}$.

\footnotetext{
${ }^{18)}$ Muhammad Nasir, Op. Cit., hal. 94.

${ }^{19)}$ Indonesia, Undang-undang Nomor 37 Tahuun 2004 Tentang Kepailitan dan Penundaan Kewajiban Pembayaran Utang (Lembaran Negara Republik Indonesia Tahun 2004 Nomor 131, Tambahan Lembaran Negara Republik Indonesia Nomor 4443), Pasal 1 angka 1.

${ }^{20)}$ Munir Fuady, Munir Fuady, Hukum Pailit, (Bandung : Citra Aditya Bakti, 2002), hal. 8.

${ }^{21)}$ Indonesia, Kitab Undang-Undang Hukum Perdata (Burgerlijk Wetboek voor Indonesia), Staatsblad 1847, Pasal 1131.

${ }^{22)}$ Indonesia, Kitab Undang-Undang Hukum Perdata (Burgerlijk Wetboek voor Indonesia), Staatsblad 1847 Nomor 23, Pasal 1132.

${ }^{23)}$ Siti Anisah, Perlindungan Kepentingan Kreditur dan Debitor dalam Hukum Kepailitian di Indonesia studi Putusan-Putusan Pengadilan, (Yogyakarta: Total Media, 2008), hal. 217.
} 
Sita umum dilakukan dengan cara mengontrol semua harta kekayaan debitur dengan menunjuk kurator. Kurator berwenang melaksanakan tugas pengurusan dan/atau pemberesan atas harta pailit sejak tanggal pailit diucapkan ${ }^{24}$. Sita umum dimaksdukan untuk mencegah debitur melakukan perbuatan-perbuatan yang dapat merugikan kepentingan para krediturnya ${ }^{25}$ dan menghentikan lalu lintas transaksi terhadapa harta pailit oleh debitur yang mungkin merugikan para krediturnya sehingga harta tersebut dapat dimanfaatkan bagi kepentingan para krediturnya. Selain itu, dilakukannya sita umum menjamin agar harta debitur tidak diperebutkan oleh para krediturnya ${ }^{26}$. Ketika kreditur mengeksekusi hartanya secara sendiri-sendiri akan merugikan debitur dan kreditur yang lainnya sehingga penguasaan atas harta pailit perlu ditaruh dibawa penguasaan pengadilan hal ini sebagaimana tertuang didalam prinsip debt collection ${ }^{27}$.

Sita umum ini terjadi demi hukum sehingga tidak memerlukan suatu tindakan secara khusus atau tindakan hukum tertentu seperti halnya sita lain yang terdapat dalam hukum perdata. Semua penyitaan yang telah dilakukan menjadi hapus dan jika diperlukan Hakim Pengawas harus memerintahkan pencoretannya $^{28}$.

\section{Sita Pidana}

Didalam hukum publik khususnya hukum pidana juga mengenal sita, sita didalam hukum pidana dikenal dengan nama penyitaan. Penyitaan berdasarkan Pasal 1 angka 16 KUHAP diartikan sebai serangkaian tindakan penyidik untuk mengambil alih dan atau menyimpan dibawah penguasaannya benda bergerak

\footnotetext{
${ }^{24)}$ Indonesia, Undang-undang Nomor 37 Tahuun 2004 Tentang Kepailitan dan Penundaan Kewajiban Pembayaran Utang (Lembaran Negara Republik Indonesia Tahun 2004 Nomor 131, Tambahan Lembaran Negara Republik Indonesia Nomor 4443), Pasal 16.

${ }^{25}$ )Siti Anisah, Op.Cit., hal. 217.

${ }^{26)}$ Hadi M.Shubhan, Op.Cit., hal. 217.

${ }^{27)}$ Siti Hapsah Isfardiyana, "Sita Umum Kepailitan Mendahului Sita Pidana dalam Pemberesan Harta Pailit”, Padjajaran Jurnal Ilmu Hukum, Volume 3 Nomor 3 Tahun 2016.

${ }^{28)}$ Indonesia, Undang-undang Nomor 37 Tahuun 2004 Tentang Kepailitan dan Penundaan Kewajiban Pembayaran Utang (Lembaran Negara Republik Indonesia Tahun 2004 Nomor 131, Tambahan Lembaran Negara Republik Indonesia Nomor 4443), Pasal 31 ayat (2).
} 
atau tidak bergerak, berwujud atau tidak berwujud untuk kepentingan pembuktian dalam penyidikan, penuntutan dan peradilan.

Penyitaan merupakan suatu tindakan "upaya paksa" yang dilakukan penyidik untuk mengambil atau merampas hak milik orang lain. Karena penyitaan merupakan bentuk "upaya paksa" yang dapat bertentangan dengan hak asasi manusia, penyitaan yang dilakukan oleh penyidik haruslah berdasarkanan para surat izin Ketua Pengadilan Negeri sebagaimana yang diatur didalam Pasal 38 ayat (1) KUHAP ${ }^{29}$. Penyitaan digunakan oleh penyidik untuk mengamankan benda yang berkaitan dengan perkara yang sedang disidik, dituntut, atau diperadilankan agar tidak hilang atau dimusnahkan oleh tersangka atau terdakwa untuk dijadikan barang bukti dalam perkara tersebut. Perkara pidana yang akan diajukan di depan pengadilan harus dilengkapi dengan barang bukti. Penyidik berwenang memerintahkan kepada orang yang menguasai benda yang dapat disita, menyerahkan benda tersebut kepadanya untuk kepentingan pemeriksaan dan kepada yang menyerahkan benda itu harus diberikan suatu tanda penerimaan $^{30}$.

Penyitaan dalam hukum acara pidana merupakan upaya paksa yang dilakukan penyidik untuk:

1. Mengambil atau merampas sesuatu barang tertentu dari seorang tersangka, pemegang, atau peyimpan. Tapi perampasan yang dilakukan dibenarkan hukum dan dilaksanakan menurut aturan undang-undang, bukan perampasan liar dengan cara melawan hukum;

2. Setelah barangnya diambil atau dirampas oleh penyidik, barang tersebut ditaruh atau disimpan di bawah kekuasaannya ${ }^{31}$.

Terdapat beberapa bentuk penyitaan menurut KUHAP yakni;

\footnotetext{
${ }^{29)}$ M. Yahya Harahap, Op. Cit., hal. 276.

$\left.{ }^{30}\right)$ Indonesia, Undang-Undang No. 8 Tahun 1981 Tentang Kitab Undang-Undang Hukum Acara Pidana (Lembaran Negara Republik Indonesia Nomor 76, Tambahan Lembaran Negara Republik Indonesia Nomor 3209), Pasal 42 ayat (1) KUHAP.

${ }^{31)}$ M. Yahya Harahap, Op. Cit., hal. 286.
} 
1. Penyitaan biasa, penyitaan dengan bentuk dan tata cara biasa ini merupakan aturan hukum penyitaan;

2. Penyitaan dalam keadaan perlu dan mendesak sebagai pengecualian penyitaan biasa, maka Pasal 38 ayat (2) KUHAP memberi kemungkinan malakukan penyitaan tanpa melalui tata cara biasa;

3. Penyitaan dalam keadaan tertangkap tangan. Penyitaan dalam keadaan tertangkap tangan diatur dalam Pasal 40 dan Pasal 41 KUHAP;

4. Penyitaan terhadap surat atau tulisan lain penyitaan terhadap surat atau tulisan lain diatur dalam Pasal 43 KUHAP.

Benda-benda yang dapat disita diatur dalam Pasal 39 ayat (1) KUHAP, sebagai berikut:

1. Benda atau tagihan tersangka atau terdakwa yang seluruh atau sebagian diduga diperoleh dari tindak pidana atau sebagai hasil dari tindak pidana;

2. Benda yang telah dipergunakan secara langsung untuk melakukan tindak pidana atau untuk mempersiapkannya;

3. Benda yang dipergunakan untuk menghalang-halangi penyidikan tindak pidana;

4. Benda yang khusus dibuat atau diperuntukkan melakukan tindak pidana;dan

5. Benda lain yang mempunyai hubungan langsung dengan tindak pidana yang dilakukan.

Kemudian, dalam Pasal 39 ayat (2) KUHAP ditentukan bahwa benda yang berada dalam sitaan karena perkara perdata atau karena pailit dapat juga disita untuk kepentingan penyidikan, penuntutan dan mengadili perkara pidana, sepanjang memenuhi ketentuan ayat (1). Benda-benda sitaan tersebut harus 
disimpan dalam rumah penyimpanan benda sitaan negara (RUP BASAN) ${ }^{32}$. Penyimpanan benda sitaan dilaksanakan dengan sebaik-baiknya dan tanggung jawab atasnya ada pada pejabat yang berwenang sesuai dengan tingkat pemeriksaan dalam proses peradilan dan benda tersebut dilarang untuk dipergunakan oleh siapa pun juga ${ }^{33}$. Selama belum ada rumah penyimpanan benda sitaan negara di tempat yang bersangkutan, penyimpanan benda sitaan tersebut dapat dilakukan di kantor kepolisian, pemerintah dan dalam keadaan memaksa di tempat penyimpanan lain atau tetap di tempat semula benda itu $\operatorname{disita}^{34}$.

Berakhirnya penyitaan:

1. Penyitaan dapat berakhir sebelum ada putusan hakim, apabila

a. Kepentingan penyidikan dan penuntutan tidak memerlukannya lagi;

b. Perkara tersebut tidak jadi dituntut karena tidak cukup bukti atau bukan merupakan tindak pidana;

c. Perkara tersebut dikesampingkan untuk kepentingan umum atau perkara tersebut ditutup demi hukum, keccuali apabila benda itu diperoleh dari suatu tindak pidana atau yang dipergunakan untuk melakukan suatu tindak pidana ${ }^{35}$.

\footnotetext{
${ }^{32)}$ Indonesia, Undang-Undang No. 8 Tahun 1981 Tentang Kitab Undang-Undang Hukum Acara Pidana (Lembaran Negara Republik Indonesia Nomor 76, Tambahan Lembaran Negara Republik Indonesia Nomor 3209), Pasal 44 ayat (1) KUHAP.

${ }^{33)}$ Indonesia, Undang-Undang No. 8 Tahun 1981 Tentang Kitab Undang-Undang Hukum Acara Pidana (Lembaran Negara Republik Indonesia Nomor 76, Tambahan Lembaran Negara Republik Indonesia Nomor 3209), Pasal 44 ayat (2) KUHAP.

${ }^{34)}$ Indonesia, Undang-Undang No. 8 Tahun 1981 Tentang Kitab Undang-Undang Hukum Acara Pidana (Lembaran Negara Republik Indonesia Nomor 76, Tambahan Lembaran Negara Republik Indonesia Nomor 3209), Penjelasan Pasal 44 ayat (1) KUHAP

${ }^{35}$ Indonesia, Undang-Undang No. 8 Tahun 1981 Tentang Kitab Undang-Undang Hukum Acara Pidana (Lembaran Negara Republik Indonesia Nomor 76, Tambahan Lembaran Negara Republik Indonesia Nomor 3209), Pasal 46 ayat (1) KUHAP
} 
Terhadap benda yang dikenakan penyitaan, dikembalikan kepada orang atau kepada mereka dan siapa benda itu disita, atau kepada orang atau kepada mereka yang paling berhak

2. Penyitaan berakhir setelah putusan hakim, maka benda yang dikenakan penyitaan dikembalikan kepada orang atau kepad a mereka yang disebut dalam putusan tersebut keciali jika menurut putusan hakim benda itu dirampas untuk negara, untuk dimusnahkan atau untuk dirusakkan sampai tidak dipergunakan lagi atau jika benda tersebut masih diperlukan sebagai barang bukti dalam perkara lain ${ }^{36}$.

\section{Wawancara}

a. Dr. Munir Fuady, S.H., M.H., LL. M.

(Ahli Hukum Kepailitan)

Sebelum menentukan sita pidana atau sita umum yang memiliki kedudukan lebih tinggi maka pertama kita harus melihat dulu konsep sita pidana ataupun sita umum. Sita umum itu menyita terhadap semua harta sedangkan sita pidana terhadap harta tertentu saja, dimana menurut teori hukum sita umum itu lebih tinggi dari pada sita lain manapun kecuali ditentukan lain oleh Undang-undang. Maksudnya sita umum memiliki kedudukan lebih tinggi dari sita lainnya sepanjang diperbolehkan untuk dilakukan sita tertentu maka sita yang ditentukan oleh ketentuan tersebut memiliki kedudukan yang lebih tinggi dari sita umum. Penyitaan boleh dilakukan terhadap benda yang telah disita umum hal dikarenakan dua hal, pertama karena ditentukan oleh Undangundang dalam hal ini KUHAP dan kedua karena kepentingan

\footnotetext{
${ }^{36)}$ Indonesia, Undang-Undang No. 8 Tahun 1981 Tentang Kitab Undang-Undang Hukum Acara Pidana (Lembaran Negara Republik Indonesia Nomor 76, Tambahan Lembaran Negara Republik Indonesia Nomor 3209), Pasal 46 ayat (2) KUHAP
} 
umum, dimana benda yang disita dijadikan barang bukti dalam rangka untuk membuktikan tindak pidana yang dilakukan. Dengan adanya sita pidana terhadap benda yang disita umum maka eksekusi yang dilakukan oleh kurator harus ditunda dulu sampai kedudukan benda yang telah disita umum yang dijadikan barang bukti ditentukan oleh hakim.

b. Muhammad Deni, S.H., M.H. (Kurator KSP Pandawa Mandiri Group)

Terkait dengan kedudukan sita umum dengan sita pidana, pertama kehadiran lebih dari satu sita terhadap satu benda sangatlah dimungkinkan dan kedua sita umum mempunyai kedudukan yang tertinggi diatas seluruh sita yang lainnya kecuali terhadap sita pidana namun demikian sita pidana itu sendiri bersifat sementara dalam rangka pembuktian dalam proses penyidikan, penuntutan, persidangan sehingga pada akhirnya status hukum terhadap barang bukti yang disita akan ditentukan berdasarkan putusan pidana. Namun walaupun demikian kehadiran sita pidana terhadap benda yang telah di sita umum tidak mengakibatkan hilangnya atau hapusnya sita umum, sita umum akan selalu melekat terhadap benda yang disita umum meskipun di benda tersebut terdapat sita selain sita umum. Sita umum akan hapus ketika benda yang disita umum telah dijual untuk pemenuhan tagihan kreditor. Dasar mengapa kedudukan sita pidana memiliki kedudukan yang lebih tinggi dari pada sita umum tidak terlepas dari sita pidana yang merupakan bagian dari hukum publik sedangkan sita umum merupakan bagian dari ranah hukum perdata (hukum privat), hukum publik sifatnya harus didahulukan dibandingkan hukum privat itu lah mengapa kedudukan sita pidana memiliki tingakatan yang lebih tinggi dari pada sita umum. 


\section{B. Analisa}

\section{Kedudukan Sita Pidana Terhadap Sita Umum Kepailitan}

Dengan diucapkannya putusan pernyataan pailit maka debitor demi hukum akan kehilangan haknya untuk menguasai dan mengurus kekayaannya yang termasuk dalam harta pailit, seluruh kekayaan debitor baik yang telah ada ataupun yang diperoleh selama proses kepailitan secara otomatis akan diletakkan sita umum untuk dilakukan pengurusan dan pemberesan oleh Kurator dibawah pengawasan Hakim Pengawas. Peletakkan sita umum atas seluruh kekayaan debitor baik yang telah ada atau pun yang diperoleh selama proses kepailitan dimaksudkan untuk melindungi kepentingan kreditur terhadap perbuatan debitor yang dapat merugikan harta pailit dan untuk menjamin agar harta debitor tidak diperebutkan oleh para krediturnya namun dapat dibagikan oleh Kurator sesuai dengan prinsip pari passu prorata parte.

Peletakkan sita umum diseluruh harta milik debitor pailit terjadi demi hukum sehingga tidak memerlukan suatu tindakan secara khusus atau tindakan hukum tertentu seperti halnya sita lain, dengan adanya sita umum maka semua penyitaan yang telah dilakukan menjadi hapus dan jika diperlukan Hakim Pengawas harus memerintahkan pencoretannya sebagimana yang dinyatakan di dalam Pasal 31 ayat 2 UUK-PKPU. Sita umum sendiri merupakan bentuk penyitaan yang dikenal dalam rezim hukum perdata khususnya hukum kepailitan yang bersifat hukum privat. Didalam hukum publik dalam hal ini hukum pidana juga mengenal sita yang didalam Kitab Undang-undang Hukum Acara Pidana (KUHAP) disebut dengan penyitaan. Penyitaan dalam Pasal 1 angka 16 didefiniskan sebagai serangkaian tindakan penyidik untuk mengambil alih dan atau menyimpan dibawah penguasaannya benda bergerak atau tidak bergerak, berwujud atau tidak berwujud untuk kepentingan pembuktian dalam penyidikan, penuntutan dan peradilan.

Pasal 39 ayat (1) KUHAP memberikan kewenangan kepada penyidik untuk melakukan penyitaan terhadap; 
a. Benda atau tagihan tersangka atau terdakwa yang seluruh atau sebagian diduga diperoleh dan tidak pidana atau sebagian hasil dan tidak pidana;

b. Benda yang telah digunakan secara langsung untuk melakukan tindak pidana atau untuk mempersiapkannya;

c. Benda yang dipergunakan untuk menghalang-halangi penyidikan tindak pidana;

d. Benda yang khusus dibuat dan diperuntukkan melakukan tindak pidana

e. Benda lain yang mempunyai hubungan langsung dengan tindak pidana yang dilakukan

penyidik juga diberikan kewenangan di dalam Pasal 39 ayat (2) KUHAP, untuk melakukan penyitaan terhadap benda yang berada dalam sitaan karena perkara perdata atau karena pailit untuk kepentingan penyidikan, penuntutan, dan mengadili perkara pidana, sepanjang memenuhi ketentuan ayat (1). Kewenangan yang diberikan KUHAP kepada penyidik untuk melakukan penyitaan terhadap benda yang telah disita dalam perkara perdata atau karena pailit tidak terlepas dari dibutuhkannya benda tersebut untuk dijadikan barang bukti untuk membuktikan suatu tindak pidana.

Menurut Pasal 39 ayat (2) KUHAP penyidik memiliki hak untuk melakukan penyitaan terhadap benda yang telah berada dalam sita umum kepailitan akan tetapi di dalam Pasal 31 ayat (2) UUK-PKPU mengatur bahwa semua penyitaan yang telah dilakukan menjadi hapus dan jika diperlukan hakim pengawas harus memerintahkan pencoretannya. Kedua pasal ini menimbulkan benturan dan permasalahan dalam penerapannya, salah satun kasus yang berkaitan tentang sita umum yang kemudian di sita pidana ialah kasus Koperasi Pandawa Mandiri Group.

Koperasi Pandawa Mandiri Group berdasarkan Putusan No. 37/Pdt-SusPKPU/2017/PN Niaga Jkt.Pst dinyatakan pailit bersamaan dengan pendirinya yang juga sekaligus pengurus yakni Salman Nuryanto. Konsekuensi hukum dengan adanya pernyataan pailit tersebut sebagaimana disebutkan diawal bahwa seluruh harta benda milik debitor pailit (KSP Pandawa Mandiri Group \& Salman Nuryanto) akan diletakkan sita umum. Setelah diletakkan sita umum, Salman Nuryanto diduga telah 
melakukan tindak pidana melanggar Pasal 46 Ayat (1) Undang-Undang (UU) Nomor 10 Tahun 1998 Tentang Perubahan Atas UU Nomor 7 Tahun 1992 Tentang Perbankan, jo Pasal 69 UU Nomor 21 Tahun 2011 Tentang OJK, jo Pasal 55 ayat (1) ke-1 jo Pasal 64 Ayat (1) KUHP dan Pasal 378 KUHP Tentang Penipuan, jo Pasal 55 ayat (1) jo Pasal 64 ayat (1) KUHP. Dengan adanya dugaan tindak pidana yang dilakukan oleh Salman Nuryanto yang merupakan pendiri dan juga pengurus dari KSP Pandawa Mandiri Group, penyidik (Polda Metro jaya) melakukan penyitaan terhadap benda yang telah diletakkan sita umum.

Akibatnya terdapat dua sita diatas satu benda padahal Pasal $436 \mathrm{Rv}$ mengatur bahwa barang yang telah diletakkan sita, tidak bisa dilakukan sita untuk kedua kalinya. Hal ini menegaskan bahwa tidak dimungkinkan meletakkan sita umum kepailitan dan sita pidana dalam waktu yang bersamaan. Dengan adanya benturan antara sita umum dan sita pidana berakibat timbulnya ketidakpastiaan hukum, agar terciptanya kepastiaan hukum harus ditentukan sita mana yang harus didahulukan, lalu bagaimana sebenarnya kedudukan sita pidana atas sita umum kepailitan.

Untuk memberikan kepastian hukum tentang sita mana yang harus didahulukan dan bagaimana kedudukan sita pidana atas sita umum maka dapat dilihat dari dua hal; pertama dari isi atau kepentingan yang diaturnya dan kedua dari akibatnya. Berdasarkan isi atau kepentingan yang diaturnya, hukum dapat dibedakan atas dua jenis, yaitu hukum privat dan hukum publik. Hukum privat ialah hukum yang mengatur kepentingan pribadi dan cara mempertahankannya dilakukan oleh masingmasing individu sedangkan hukum publik ialah hukum yang mengatur kepentingan publik atau kepentingan umum dan cara mempertahankannya dilakukan oleh aparat negara $^{37}$. Sudikno Mertokusumo menyebutkan perbedaan antara hukum publik dan hukum privat (perdata) adalah sebagai berikut:

a. Dalam hukum publik salah satu pihak adalah penguasa, sedangkan dalam hukum perdata kedua belah pihak adalah perorangan tanpa

\footnotetext{
37) Marwan Mas, Pengantar Ilmu Hukum, (Bogor: Ghalia Indonesia, 2014), hal 77.
} 
menutup kemungkinan bahwa dalam hukum perdatapun penguasa dapat menjadi pihak juga.

b. Sifat hukum publik memaksa, sedangkan hukum perdata pada umumnya bersifat melengkapi meskipun ada juga yang memaksa.

c. Tujuan hukum publik adalah melindungi kepentingan umum, sedangkan hukum perdata melindungin kepentingan individu/perorangan.

d. Hukum publik mengatur hubungan hukum antara Negara dengan individu, sedangkan hukum perdata mengatur hubungan hukum antara individu..

Sita pidana yang dikenal di dalam KUHAP dengan sebutan penyitaan merupakan bentuk penyitaan yang merupakan bagian dari hukum publik, karakteristik hukum publik yang bertujuan untuk mengatur dan melindungi kepentingan umum menjadikan hukum publik memiliki kekhususan tersendiri dibandingkan dengan hukum privat. Kekhususan tersebut mengakibatkan hukum publik harus didahulukan terlebih dahulu dibandingkan dengan hukum privat. Dan penyitaan yang dilakukan penyidik adalah untuk menegakkan hukum publik dalam hal ini hukum pidana. Untuk itu walaupun suatu benda yang telah disita dalam kepailitan harus pula dapat di sita pidana kembali, hal ini bertujuan untuk melindungi kepentingan umum sebagaimana tujuan dari hukum publik (hukum pidana). Dalam hal sita pidana berbenturan dengan sita umum maka sudah seharusnya sita pidana yang harus didahulukan dibandingkan dengan sita umum. Hal ini disebabkan disamping untuk melindungi kepentingan umum juga disebabkan karena karakteristik dari hukum publik yang bersifat memaksa sehingga ketentuan sita pidana dapat dilakukan meskipun diatas benda tersebut telah ada sita umum.

Jika dilihat dari akibat, jika suatu benda yang telah disita umum tidak dapat dilakukan sita pidana maka akibatnya suatu tindak pidana akan sulit dibuktikan. Misalnya jika debitur pailit juga diduga telah melakukan tindak pidana korupsi, namun karena adanya sita umum maka benda yang diduga digunakan atau merupakan hasil korupsi tidak dapat disita pidana maka benda tersebut tidak dapat digunakan 
untuk membuktikan tindak pidana ataupun untuk membayar ganti kerugian akibat dari tindak pidana korupsi yang diduga dilakukan oleh debitur pailit. Namun jika misalnya benda yang telah di sita umum kemudian di sita pidana maka hanya akan menimbulkan dampak kurator menunda untuk melakukan eksekusi terhadap benda yang di sita pidana tersebut.

Jelas akibat dari sita umum yang tidak dapat disita pidana akan menimbulkan dampak yang lebih besar terhadap kepentingan umum dibandingkan dengan akibat jika suatu benda yang di sita umum dapat di sita pidana kembali. Dengan lebih tingginya sita pidana dibandingkan sita umum maka sita pidana harus didahulukan. Lagi pula penyitaan (sita pidana) hanya bersifat sementara karena setelah selesai digunakan untuk pembuktian barang bukti yang merupakan benda yang telebih dahulu disita umum akan dikembalikan jika menurut pertimbangan hakim benda tersebut dikembalikan kepada siapa benda itu disita. Setelah dikembalikan maka kurator dapat kembali melanjutkan tugasnya untuk melakukan pengurusan dan pelunasan utang debitor kepada kreditur. Dengan adanya sita pidana diatas benda yang telah disita umum tidak mengakibatkan sita umumnya hapus, sita umum akan tetap melekat meskipun dibenda tersebut terdapat sita lainnya.

Didahulukannya sita pidana dibandingkan sita umum juga didukung pendapat dari Dr. Munir Fuady, S.H., M.H., LL. M., beliau mengatakan menurut teori hukum sita umum itu lebih tinggi dari pada sita lain manapun kecuali ditentukan lain oleh Undang-undang. Maksudnya sita umum memiliki kedudukan lebih tinggi dari sita lainnya sepanjang diperbolehkan untuk dilakukan sita tertentu maka sita yang ditentukan oleh ketentuan tersebut (sita pidana) memiliki kedudukan yang lebih tinggi dari sita umum. Sederhananya jika sita pidana berbenturan dengan sita umum maka sita pidanalah yang harus didahulukan. Penyitaan boleh dilakukan terhadap benda yang telah disita umum hal dikarenakan dua hal, pertama karena ditentukan oleh Undang-undang dalam hal ini KUHAP dan kedua karena kepentingan umum, dimana benda yang disita dijadikan barang bukti dalam rangka untuk membuktikan tindak pidana yang dilakukan. Dengan adanya sita pidana terhadap benda yang disita 
umum maka eksekusi yang dilakukan oleh kurator harus ditunda dulu sampai kedudukan benda yang telah disita umum yang dijadikan barang bukti ditentukan oleh hakim.

Hal senada juga disampaikan oleh Muhammad Deni, S.H., M.H., yang merupakan salah satu anggota dari Tim Kurator KSP Pandawa Mandiri Group, beliau mengamini bahwa sita pidana memiliki kedudukan yang lebih tinggi dari sita umum maka harus didahulukan dibandingkan oleh sita umum, beliau mengatakan sita umum mempunyai kedudukan yang tertinggi diatas seluruh sita yang lainnya kecuali terhadap sita pidana. Dasar mengapa kedudukan sita pidana memiliki kedudukan yang lebih tinggi dari pada sita umum tidak terlepas dari sita pidana yang merupakan bagian dari hukum publik sedangkan sita umum merupakan bagian dari ranah hukum perdata (hukum privat), hukum publik sifatnya harus didahulukan dibandingkan hukum privat itu lah mengapa kedudukan sita pidana memiliki tingakatan yang lebih tinggi dari pada sita umum.

\section{PENUTUP}

\section{A. Kesimpulan}

Sita pidana mendahului sita umum kepailitan dalam hal kedua sita tersebut terdapat dalam satu benda, hal tersebut disebabkan karena sita pidana (penyitaan) yang dikenal dalam hukum pidana merupakan bagian dari hukum publik. Karakteristik hukum publik yang bertujuan untuk mengatur dan melindungi kepentingan umum menjadikan hukum publik memiliki kekhususan tersendiri untuk didahulukan dibandingkan dengan hukum privat. Jika dilihat dari akibat, akibat dari sita umum yang tidak dapat disita pidana akan menimbulkan dampak yang lebih besar terhadap kepentingan umum dibandingkan dengan akibat jika suatu benda yang di sita umum dapat di sita pidana kembali sehingga sudah seharusnya sita pidana memiliki kedudukan yang lebih tinggi dibandingkan sita umum dan harus didahulukan. 


\section{B. Saran}

Berdasarkan hasil penelitian yang dilakukan oleh penulis terkait kedudukan sita pidana terhadap sita umum kepailitan, maka penulis memberikan saran sebagai berikut;

1. Perlunya kesepahaman antar penegak hukum bahwa sita pidana akan selalu mendahului sita umum kepailitan sehingga tidak lagi terjadi perdebatan terkait permasalahan ini;

2. Perlunya peran aktif dari kurator untuk turut serta mengawasi benda yang disita pidana, agar benda yang disita pidana yang merupakan boedel pailit dikembalikan kepada kurator;

\section{Daftar Pustaka}

\section{A. Buku}

Fuady, Munir. Hukum Pailit. (Bandung: Citra Aditya Bakti, 2002)

Harahap, M. Yahya. Permbahasan Permasalahan Dan Penerapan KUHAP Penyidikan dan Penuntutan. (Jakarta: Sinar Grafika, 2001)

Hartini, Rahayu. Hukum Kepailitan. (Malang: Penerbitan Universitas Muhammadiyah Malang, 2012)

Mahadi. Falsafah Hukum. (Bandung: Alumni, 2003)

Marzuki, Peter Mahmud. Penelitian Hukum. Cetakan ke-9. Edisi Revisi. (Jakarta: Kencana, 2016).

Mertokusumo, Sudikno. Mengenal Hukum Suatu Pengantar. (Yogyakarta: Liberty, 2005)

Mulyadi Kartini. Penyelesaian Utang Piutang Melalui Pailit atau Penundaan Kewajiban Pembayaran Utang. (Bandung: Alumni, 2001) 
Rahardjo, Satjipto. Ilmu Hukum. (Bandung: Penerbit Alumni, 1986)

Shubhan, M. Hadi. Hukum Kepailitan. Cetakan ke-2, (Jakarta: Prenadamedia Group, 2009)

Sjahdeini, Sutan Remy. Sejarah, Asas, dan Teori Hukum Kepailitan Memahami Undang-Undang No. 37 Tahun 2004. (Jakarta: Prenadamedia Group, 2016)

Subekti, R. Pokok-Pokok Hukum Dagang. (Jakarta: Intermasa, 1995)

\section{B. Peraturan Perundang-undangan Nasional}

Indonesia. Undang-Undang Dasar Negara Republik Indonesia Tahun 1945, Cetakan keenam, (Jakarta: Kepaniteraan dan Sekretariat Jenderal Mahkamah Konstitusi RI, 2016). . Undang-undang Nomor 37 Tahuun 2004 tentang Kepailitan dan Penundaan Kewajiban Pembayaran Utang (Lembaran Negara Republik Indonesia Tahun 2004 Nomor 131, Tambahan Lembaran Negara Republik Indonesia Nomor 4443).

- Undang-Undang Nomor 8 Tahun 1981 tentang Hukum Acara Pidana, (Lembaran Negara No.76 Tahun 1981, Tambahan Lembaran Negara No. 3209)

Kitab Undang-Undang Hukum Perdata [Burgerlijk Wetboek], Diterjemahkan oleh Subekti dan R. Tjitrosudibio. Jakarta : Pradnya Paramita, 2008.

\section{Jurnal}

Siti Hapsah Isfardiyana. "Sita Umum Kepailitan Mendahului Sita Pidana dalam Pemberesan Harta Pailit”. Padjajaran Jurnal Ilmu Hukum. Volume 3 Nomor 3 Tahun 2016. 